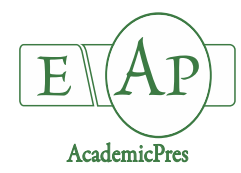

Horvath KZ et al. (2020)
Notulae Botanicae Horti Agrobotanici Cluj-Napoca 48(3):1233-1247
DOI: $10.15835 /$ nbha48311963
Research Article

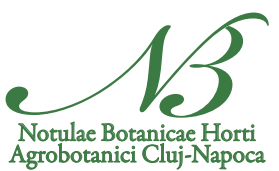

\title{
Effect of mycorrhizal inoculations on physiological traits and bioactive compounds of tomato under water scarcity in field conditions
}

\author{
Kitti Z. HORVÁTH, Bulgan ANDRYEI, Lajos HELYES, Zoltán PÉK, \\ András NEMÉNYI, Eszter NEMESKÉRI*
}

\author{
Szent István University, Faculty of Agricultural and Environmental Science, Institute of Horticulture, H-2100 Gödöllö, Páter K. \\ Street 1, Hungary; horvath.kitti.zsuzsanna@gmail.com; bulgan.mgl@muls.edu.mn; Helyes.Lajos@mkk.szie.hu; \\ pek.zoltan@mkk.szie.hu; Nemenyi.Andras@mkk.szie.hu; Nemeskeri.Eszter@mkk.szie.hu ("correspondingauthor)
}

\begin{abstract}
Mycorrhizal inoculations were investigated to reveal their effects on the growth and productivity of processing tomato grown under field conditions. Plants inoculated at sowing (M1), sowing + transplanting (M2) and non-inoculated plants (M0) were grown under regularly irrigated (RI), deficit irrigated (DI), and non-irrigated (I0) conditions. In dry years, under non-irrigated conditions (M2) treatment significantly decreased the canopy temperature, improved the photosynthetic efficiency expressed by chlorophyll fluorescence $(\mathrm{Fv} / \mathrm{Fm})$ and the fruit setting, significantly increased the total carotenoids and lycopene concentration of fruits but increased the ratio of green yield. Using deficit irrigation, (M2) plants produced more and larger weighed red fruits than (M1) plants but the $\beta$ carotene, lutein and lycopene concentration of fruits, except for the vitamin $\mathrm{C}$, decreased. Under severe drought conditions the mycorrhizal inoculations positively influenced the all carotenoids and lycopene concentration of fruits $(r=0.8150, r=0.7837)$, but their impact was negative under deficit irrigation. Under water deficiency (I0, DI) the mycorrhizal symbiosis increased the marketable yield and resulted in a 33\% increase in green yield and an $18 \%$ increase in the total carotenoids content in dry years but the unmarketable yield decreased. Under water deficiency (M2) treatment produce more marketable yield resulting in $9.8 \%$ higher total carotenoids in the tomato fruits than (M1) treatment under field conditions.
\end{abstract}

Keywords: arbuscular mycorrhiza; carotenoids; chlorophyll fluorescence; tomato; water stress

\section{Introduction}

The frequency of extreme climatic factors such as high temperature, water deficiency limits the production of horticultural crops in open-field conditions. High temperature occurring during reproductive growth stages of tomato impedes the fruit setting (Helyes et al., 2000) which can lead to a decrease in the yield. Water deficiency decreases the yield of tomato but increases the soluble solid content of yield in comparison with that of well-irrigated plants (Pék et al., 2019). These negative impacts on tomato yield could be moderated by the implementation of deficit irrigation strategies based on restitution of $60-70 \%$ of crop evapotranspiration (Giuliani et al., 2019). It has been shown, using deficit irrigation, that the decrease in the yield was not 
considerable and the quality of yield including sugar and antioxidants could be improved, however these results concerning the yield quality have been contradictory (Favati et al., 2009; Agbna et al., 2017).

Tomato is one of the most important vegetable crops containing bioactive compounds such as phenolic compounds, carotenoids, vitamins and glycoalkaloids that help prevent chronic diseases, such as cancer and cardiovascular disease (Agarwal and Rao, 2000). So far, 20 different carotenoids have been detected in tomatoes in which lycopene is accounted for $70-90 \%$ of the carotenoids providing the red colour of fruits and the $\beta$ carotene and lutein content is also remarkable (Chaudhary et al., 2018). It was found that carotenoid content of green tomato fruits is similar to tomato leaves being basically carotene, lutein and violaxanthin. Nevertheless, during fruit ripening the genes mediating in lycopene synthesis are upregulated therefore accumulation of lycopene, $\beta$ carotene and lutein became intensive in the ripe fruits (Dharmapuria et al., 2002). Lycopene occurs essentially in the all-trans configuration in the fresh tomato fruits that converts to cis isomer during processing involving freezing, cooking while the bioavailability of cis lycopene isomers is higher in the human organism than the trans lycopene in fresh tomato fruits (Shi and Le Maguer, 2000). The lycopene content of tomatoes is influenced by many factors, mainly the variety and environmental factors, especially temperature, light and water supply (Helyes et al., 2007; 2012). Lutein has been shown to have beneficial health effects because it retards the development of eye diseases such as age-related macular degeneration (Tan et al., 2008; Frede et al., 2017) and it has antioxidant properties (Steiner et al., 2018). Humans are unable to biosynthesize carotenoids, but they can modify some of them by consuming plants, such as $\beta$ carotene, which is converted to retinol (Baranska et al., 2006). The fundamental precursor for retinoid is $\beta$ carotene which is also referred to as provitamin A (Lira et al., 2018).

Recently, research was carried out by the use of soil microbes to mitigate the negative impact of water deficiency. Arbuscular mycorrhizal (AM) fungi occurring widely in the soil can associate with the root of most plant species and this symbiosis can improve the plant performance under various environmental stresses (Augé, 2001) and may be able to augment plant tolerance to root herbivory and pathogens (Frew et al., 2020; Frew and Price, 2019; Xie et al., 2019;) and improve the soil structure (Rillig et al., 2015; 2019). Many studies established that arbuscular mycorrhiza fungi improve the nutrient and water uptake of plants (Subramanian et al., 2006; Candido et al., 2015) mitigate the detrimental effect of stresses by increasing photosynthesis and productivity (Ruiz-Sánchez et al., 2010; Ebrahim and Saleem, 2017) and improve the yield quality (Salvioli et al., 2008; Hart et al., 2015; Bona et al., 2017). AM symbiosis positively affects the tolerance to water stress in tomato however the different plant responses depend on the AM fungi species involved (Chitarra et al., 2016; Duc et al., 2018) and the severity of the stress (Rivero et al., 2018). Application of AM fungi in agricultural systems is still restricted even though many results prove the beneficial effects of microbial inoculation under greenhouse conditions, which are not always achieved in the field (O'Callaghan, 2016; Rocha et al., 2019). A few studies have examined the growth and responses of inoculated plants in open field, where the plantmycorrhiza interaction can be modified by the natural system (Rouphael et al., 2015). Although there have been a number of studies conducted on the effect of mycorrhizas on the host plant, the knowledge of the photosynthesis, productivity and yield quality of tomato using AM mixture under water deficiency is scarce.

The main goal of this study was to evaluate the effect of mycorrhizal product containing AM mixture on some physiological traits, productivity and bioactive compounds of processing tomato under water scarcity in the field conditions. In addition, the objective was to determine the appropriate inoculation method for the improvement of the fruit yield and quality of processing tomato grown under water stress conditions.

\section{Materials and Methods}

\section{Experimental designs}

In the two years (2015 and 2016), the effect of arbuscular mycorrhiza (AM) was investigated on the growth of 'Uno Rosso' $F_{1}$ processing tomato under different water supply conditions in outdoor field 
experiments. The experiments were conducted at the Experimental Farm of the Institute of Horticulture of Szent István University, Gödöllö, Hungary. The experimental soil was brown forest soil, sandy loam in texture consisting of $69 \%$ sand, $22 \%$ silt, and $9 \%$ clay, $1.57 \mathrm{~g} \mathrm{~cm}^{-3}$ bulk density, $19 \%$ field water capacity. Soil contained 6.0 and $8.6 \mathrm{mg} \mathrm{kg}^{-1}$ of $\mathrm{NO}_{3}(\mathrm{~N})$ and 14 and $8 \mathrm{mg} \mathrm{kg}^{-1} \mathrm{P}_{2} \mathrm{O}_{5}$ in 2015 and 2016 years, respectively.

Tomato seedlings have been propagated in greenhouse using special horticulture substrate (Klasmann TS3, Klasmann-Deilmann GmbH, Geeste, Germany) and inoculated with mycorrhizae and the noninoculated one represented the control (M0). The inoculation was carried out by arbuscular mycorrhizal fungi corresponding to a commercial product Symbivit - (Symbiom Ltd. Lanskroun, Czech Republic www.symbiom.cz.) which contains a mixture of spore and mycelium of Funneliformis mosseae, F. geosporum, Claroideoglomus etunicatum, C. claroideum, Rhizoglomus microaggregatum and Rhizophagus irregularis as well as spill of roots. The inoculation was applied at a dosage of $25 \mathrm{~g} \mathrm{~L}^{-1}$ substrate at sowing of tomato (M1). Four-week-old tomato seedlings of (M1) and control (M0) were transplanted in the field on 11 of May in dry year (2015) and on 4 of May in the wet (2016) year. During transplantation to the field one-half of the inoculated seedlings (M1) were inoculated again (M2) by adding $20 \mathrm{~g}$ of Symbivit per plant into the planting hole as described by Bakr et al. (2017). We used crop rotation to highlight and better separate the effect of inoculations from the indigenous AMF. The mycorrhizal root colonization in the experiments was measured according to Bakr (2018) using the method of Giovannetti and Mosse (1980) in both years (Table 1).

The experiments were carried out in two factorial experiments where the main factor was the water supply and the mycorrhizal inoculations $(\mathrm{M})$ were the second. The inoculated and non-inoculated plants were arranged in a randomized complete block designs with four repetitions. Tomato seedlings were planted in twin rows, with $0.40 \mathrm{~m}$ spacing inside the row and $1.2 \mathrm{~m}$ between adjacent twin rows. The length of rows was $10 \mathrm{~m}$, and the space between the plants in the row was $0.2 \mathrm{~m}$, with a plant density of 6.3 plants $\mathrm{m}^{-2}$.

Table 1. Mycorrhiza root colonization (\%) in dry 2015 and wet 2016

\begin{tabular}{|c|c|c|c|}
\hline \multirow{2}{*}{ Water supply } & \multirow{2}{*}{ Treatments } & 2015 & \multicolumn{2}{|c|}{ Root colonization (\%) } \\
\cline { 2 - 4 } & & 54 & 51 \\
\hline \multirow{3}{*}{ No water supply } & Control & 67 & - \\
\cline { 2 - 4 } & AM+ & 70 & 50 \\
\cline { 2 - 4 } & AM++ & 49 & - \\
\hline \multirow{3}{*}{ Half water supply } & Control & 64 & 73 \\
\cline { 2 - 4 } & AM+ & 63 & - \\
\cline { 2 - 4 } & AM++ & 55 & 70 \\
\cline { 2 - 4 } & Control & 73 & 71 \\
\hline
\end{tabular}

Bakr (2018)

During its development processing tomato requires 400 to $800 \mathrm{~mm}$ of rainfall (Battilani et al., 2012). On the basis of available water for plants shown in Table 2, the weather was dry in year 2015 and it was wet in 2016, compared to the Hungarian average (Spinoni et al., 2015). The following irrigation treatments were applied: RI-regular irrigation corresponding to the optimal water demands of plants $(100 \%$ of evapotranspiration ET), and DI-deficit irrigation provided with half of the irrigated doses of RI treatment, which was calculated by potential evapotranspiration $(\mathrm{ETc})$ and crop coefficient $(\mathrm{Kc})$ using CROPWAT 8.0 software (FAO, Rome, Italy) and I0-represented the non-irrigated plots were only under natural precipitation conditions (Table 2). The irrigation method was drip irrigation and was performed three times per week and it was finished 19 days before the harvest. In both years twenty plants were selected and tagged in every plot to measure the physiological traits.

In each year, the distribution of precipitation varied during the different stages of development of tomato. From planting to beginning of flowering a lot of rain has fallen in the wet year of $2016(112.5 \mathrm{~mm})$ but no rain was detected in the dry 2015 (Figure 1). In the 2016, during early fruit development and fruit ripening 
(ST3, ST4) a lot of rain was detected. In dry the year (2015) during flowering with fruit setting (ST2) the relatively low precipitation $(42 \mathrm{~mm})$ was associated with high temperature $\left(34^{\circ} \mathrm{C}\right)$ and during early fruit development (ST3) precipitation was low $\left(29.1 \mathrm{~mm}\right.$ ) and high air temperatures (above $30^{\circ} \mathrm{C}$ ) occurred.

Table 2. Precipitation and irrigation during the 'Uno Rosso' $F_{1}$ tomato cropping cycle of from transplanting to harvest

\begin{tabular}{|c|c|c|c|c|c|}
\hline \multirow{2}{*}{ Year } & $\begin{array}{c}\text { Precipitation } \\
(\mathrm{mm})\end{array}$ & \multicolumn{2}{|c|}{$\begin{array}{c}\text { Irrigation } \\
(\mathrm{mm})\end{array}$} & \multicolumn{2}{c|}{$\begin{array}{c}\text { Precipitation + irrigation } \\
(\mathrm{mm})\end{array}$} \\
\cline { 2 - 6 } & $\mathrm{I} 0$ & DI & RI & DI & RI \\
\hline 2015 & 101.1 & 140.6 & 262.5 & 241.7 & 363.6 \\
\hline 2016 & 315.1 & 112.6 & 211.5 & 427.7 & 526.6 \\
\hline
\end{tabular}

$\mathrm{I} 0=$ non-irrigated $\mathrm{DI}=$ deficit irrigated $\mathrm{RI}=$ regularly irrigated conditions
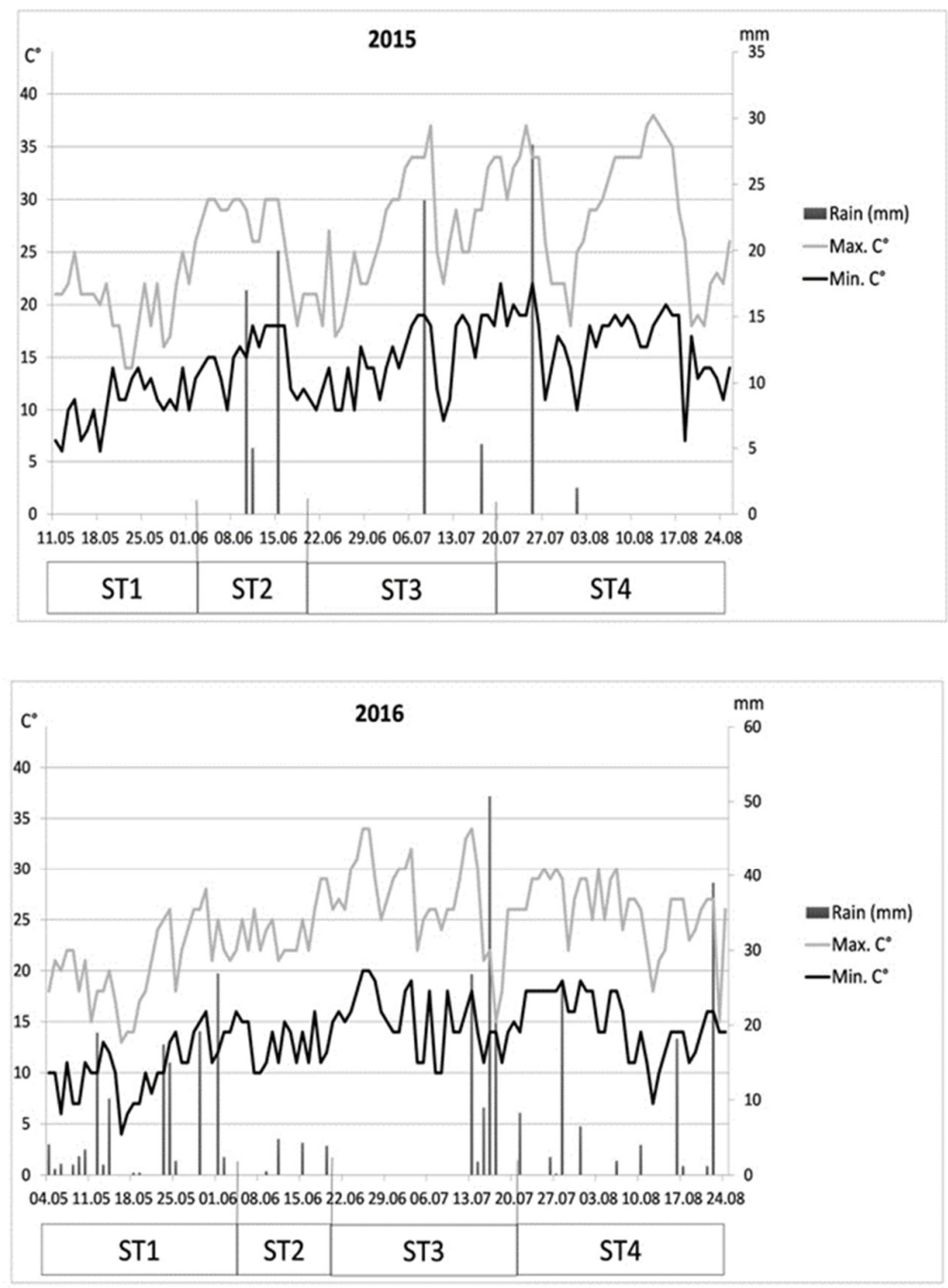

Figure 1. Meteorological data during the growth stages of processing tomato ST1=from transplantation to start of flowering, ST2= during flowering with fruit setting, ST3=early fruit development, ST4=fruit ripening stages 


\section{Measure of canopy temperature and chlorophyll fluorescence}

'Uno Rosso' $F_{1}$ processing tomato has been investigated under different water supply conditions but the effect of mycorrhizal inoculations on physiological traits and their relationship with the yield could only be evaluated in the dry year. The measurements of chlorophyll fluorescence and canopy temperature of selected plants were carried out between 10:00 and 13:00 hours on four occasions: at the beginning of flowering (ST1), during flowering with fruit setting (ST2), early fruit development (ST3) and fruit ripening (ST4) stages.

A PAM 2500 (Walz, Effeltrich, Germany) portable fluorometer was used to measure the chlorophyll fluorescence of leaves. The fluorometer measured the initial (F0) and maximal (Fm) fluorescence on darkadapted samples as described by Nemeskéri et al. (2019a). The maximum photochemical quantum yield of photosystem II (PSII) was calculated using the Fv/Fm ratio determined by the fast kinetics method in the PamWin 3.0 software (Walz, Effeltrich, Germany) (Nagy et al., 2017), where the maximum quantum yield of PSII ( $\mathrm{Fv} / \mathrm{Fm})$ expressed from the chlorophyll fluorescence was calculated on the basis of the equation: $\mathrm{Fv} / \mathrm{Fm}$ $=(\mathrm{Fm}-\mathrm{F} 0) / \mathrm{Fm}$, where $\mathrm{F} 0=$ initial fluorescence, $\mathrm{Fm}=$ maximal fluorescence, and $\mathrm{Fv}=$ variable fluorescence (Fm - F0). The canopy temperature was ground-based measured by a Raytek MX4 (Raytek Corporation, Santa Cruz, CA, USA) handheld infrared remote thermometer, at the same time as described for the measurement of chlorophyll fluorescence.

\section{Measurement of yield}

The selected plants were harvested between the $21^{\text {st }}$ and $25^{\text {th }}$ of August depending on the year. After harvest the number of fruits per plant was counted and the harvested fruits were weighed and classified. The marketable group contained the healthy red coloured tomato fruits. The healthy green coloured fruits were classified into the second group and the third group comprised of the diseased fruits. The samples of red marketable fruits in each repetition of all treatments were chemically analysed.

\section{Chemical analysis}

The chemical analysis of tomato fruits was performed in all years. The content of total soluble solids was determined by a Krüss DR201-95 handheld refractometer (A. Krüss Optronic GmbH, Hamburg, Germany) and it was given in ${ }^{\circ} \mathrm{Brix}$. The determination of vitamin $\mathrm{C}$ content of the tomato yield was carried out using high performance liquid chromatography (HPLC) (Hitachi High-Technologies Europe GmbH, Budapest, Hungary) as described by Daood et al. (1994). Lycopene from homogenized tomato was extracted with an nhexane-methanol-acetone (2:1:1) mixture and quantified spectrophotometrically at $500 \mathrm{~nm}$ and expressed in microgram per $\mathrm{g}$ fresh weight as described by Helyes et al. (2012). Identification and measurement of carotenoids was performed using HPLC analysis as described by Daood et al. (2014).

\section{Statistical analysis}

Data were evaluated by two-way analysis of variance (ANOVA) (irrigation x M inoculation) using SPSS 20.0 (IBM Hungary Ltd, Budapest, Hungary) Windows software in each year. The average values of treatments were compared by Tukey test at $\mathrm{p}<0.05$. Regression analysis was made to reveal the relationship between the physiological traits (chlorophyll fluorescence, canopy temperature) and mycorrhizal inoculations and the yield and bioactive compounds in different water supply conditions in the dry year. Linear, logarithmic, hyperbolic, power, and exponential regression analysis were carried out. The most appropriate regression equation based on the highest correlation coefficient $(r)$ and significant $\mathrm{p}$ level was interpreted.

\section{Results}

In the dry year (2015) the rate of root colonization in untreated plants (control) was significantly lower $(54,49$ and $55 \%)$ under different water supply conditions than that of once and double inoculated plants sown 
in Table 1. Nevertheless, the root colonization of (M2) was slightly higher than (M1) only under the nonirrigated condition in the dry year. In wet 2016, the rate of root colonization in control was less under nonirrigated and well-irrigated conditions than in the dry year while the rate of root inoculation of (M2) plants was higher by $37 \%$ under non-irrigated condition and by $43 \%$ under well-irrigated conditions compared to the untreated (control) plants (Table 1) (Bakr, 2018). Despite of the high colonization in control plants mycorrhizal inoculations improved the photosynthetic activity in particular in double inoculated (M2) plants.

\section{Chlorophyll fluorescence and canopy temperature}

The chlorophyll fluorescence $(\mathrm{Fv} / \mathrm{Fm})$ and canopy temperature measured during the reproductive stages of tomato changed according to the years. In a wet year (2016) a higher Fv/Fm and lower canopy temperature were detected than in the dry year. The effect of mycorrhizal inoculations on chlorophyll fluorescence ( $\mathrm{Fv} / \mathrm{Fm})$ of the leaves depended on the water supply conditions. In the dry year (2015), (M2) treatments resulted in a significant increase in $\mathrm{Fv} / \mathrm{Fm}$ under non-irrigated conditions, no change was detected in well-irrigated plants compared to control (M0) (Figure 2A). Under dry weather conditions, canopy temperature was over $26{ }^{\circ} \mathrm{C}$ however, in the wet year it was below $25{ }^{\circ} \mathrm{C}$. Under severe dry conditions, mycorrhizal inoculations (M1, M2) contributed to a decrease in canopy temperature of plants but their effect was not detected for the irrigated plants (Figure 2B). In the wet year (2016), the mycorrhizal inoculations influenced neither the chlorophyll fluorescence nor canopy temperature of tomato.
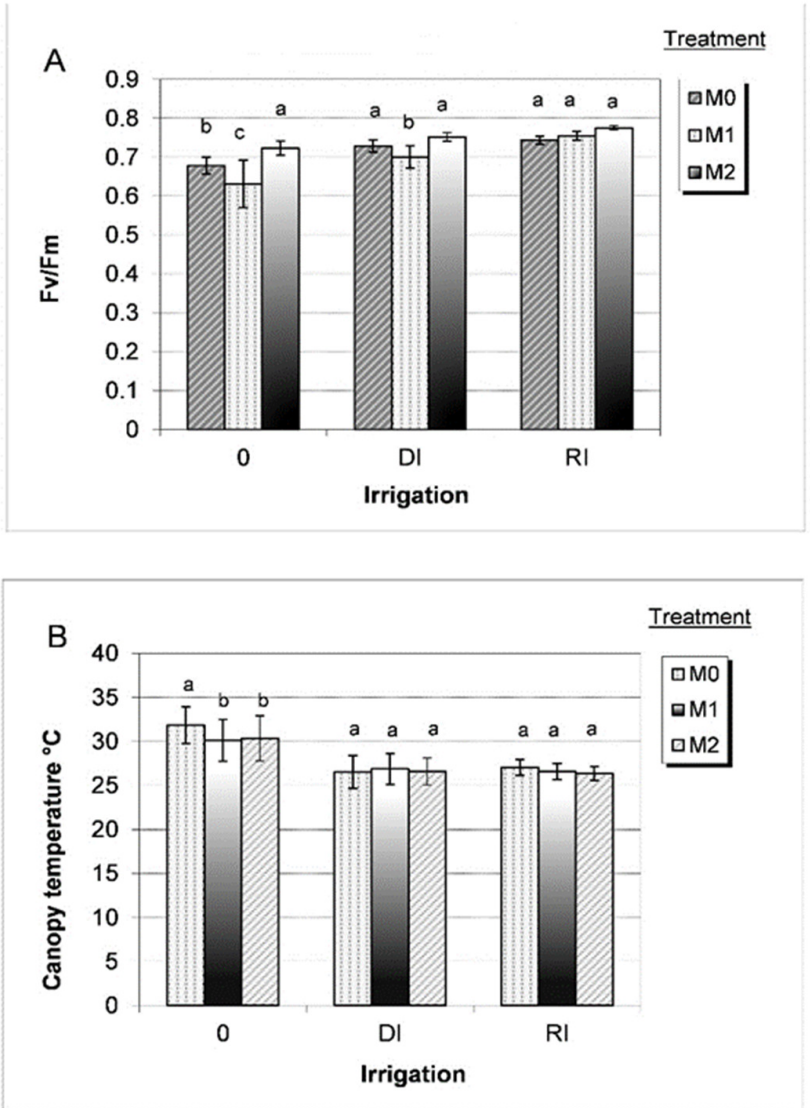

Figure 2. Effect of mycorrhizal inoculations on chlorophyll fluorescence ( $\mathrm{Fv} / \mathrm{Fm})(\mathrm{A})$ and canopy temperature (B) of tomato under different water supply conditions in the dry year

Error bar represent standard error (SE) Means following different letter are significantly different at the $\mathrm{P}<0.05$ level, $\mathrm{I} 0=$ non-irrigated $\mathrm{DI}=$ deficit irrigated $\mathrm{RI}=$ regularly irrigated conditions 


\section{Effect of water supply and mycorrhizal inoculations on the yield of processing tomato}

Years significantly influenced the fruit setting in particular the number of red and green fruits per plant and their weight. More red and green fruits with small weight were produced in 2015, nevertheless higher fruit yield and the largest ratio of diseased fruits were produced in the wet (2016) year compared to the dry year. Under dry weather conditions, irrigation (DI, RI) increased the number and weight of tomato fruits of plants, the marketable and diseased yield but in a wet year the irrigation had a small influence on both individual production (i.e. number and weight of fruits per plant) and marketable yield of tomato compared to the nonirrigated plants. Effect of mycorrhizal treatments was more predominant on the productivity of tomato in dry weather conditions than under good water supply conditions; (M2) treatment significantly increased the marketable yield compared to (M1) and untreated (M0) due to the more and larger weighed red fruits of plants and both (M1) and (M2) decreased the ratio of diseased yield.

Under severe drought (dry year, non-irrigation), both (M1) and (M2) treatments induced a prolonged ripening of fruits which realized in a larger amount of green fruit yield of tomato than in untreated (M0) plants while the marketable yield did not change in comparison with the control (M0) (Table 3). Under these conditions, the mycorrhizal treatments (M1 and M2) significantly decreased the amount of diseased yield. Using deficit irrigation (DI), (M2) inoculated plants produced significantly more red fruit with larger weight and higher marketable yield than those treated by (M1). Under these conditions, both (M1) and (M2) treatments increased the green fruit yield of tomato (Table 3). Nevertheless (M2) treatment could provide a higher marketable and green yield (50.9\% and 54\%, respectively) than in (M1) treatment in a wet (2016) year, under moderate water supply conditions (non-irrigation, deficit irrigation), mycorrhizal inoculations (M1 and M2) improved the fruit setting i.e. increased the number of red fruits per plants which contributed to a higher marketable yield than non-inoculated plants (M0), however the increase in marketable yield caused by (M2) treatment was $15.7 \%$ in comparison with (M1) one.

Table 3. Effect of water supply and mycorrhizal (M) treatments on yield of processing tomato in dry and wet years

\begin{tabular}{|c|c|c|c|c|c|c|c|}
\hline \multirow{2}{*}{ Yield } & \multirow{2}{*}{ Irrigation } & \multicolumn{3}{|c|}{ Dry year } & \multicolumn{3}{|c|}{ Wet year } \\
\hline & & M0 & M1 & M2 & M0 & M1 & M2 \\
\hline \multirow{3}{*}{ Marketable $\mathrm{t} \mathrm{ha}^{-1}$} & $\mathrm{I} 0$ & $14.69 \mathrm{a}$ & $15.16 \mathrm{a}$ & $14.92 \mathrm{a}$ & $61.22 \mathrm{~b}$ & $69.75 \mathrm{a}$ & $71.09 \mathrm{a}$ \\
\hline & DI & $56.45 \mathrm{c}^{*}$ & $63.91 b^{*}$ & $96.47 a^{*}$ & $67.61 \mathrm{~b}$ & $83.06 \mathrm{a}^{*}$ & $96.09 \mathrm{a}^{*}$ \\
\hline & RI & $68.41 b^{*}$ & $57.64 \mathrm{c}^{*}$ & $75.38 \mathrm{a}^{*}$ & $79.39 \mathrm{a}^{*}$ & $81.84 \mathrm{a}^{*}$ & $74.48 \mathrm{a}$ \\
\hline \multirow{3}{*}{ Green $\mathrm{t} \mathrm{ha}^{-1}$} & I0 & $4.06 \mathrm{c}$ & $4.57 \mathrm{~b}$ & $5.46 \mathrm{a}$ & $9.41 \mathrm{a}$ & $9.63 \mathrm{a}$ & $11.05 \mathrm{a}$ \\
\hline & DI & $3.73 \mathrm{c}$ & $5.83 \mathrm{~b}$ & $8.98 \mathrm{a}^{*}$ & $12.97 \mathrm{a}^{*}$ & $12.22 \mathrm{a}^{*}$ & $9.77 \mathrm{a}^{*}$ \\
\hline & RI & $2.89 \mathrm{a}^{*}$ & $1.51 b^{*}$ & $2.84 \mathrm{a}^{*}$ & $6.83 \mathrm{a}^{*}$ & $9.64 \mathrm{a}$ & $12.81 \mathrm{a}$ \\
\hline \multirow{3}{*}{ Disease $\mathrm{t} \mathrm{ha}^{-1}$} & I0 & $1.08 \mathrm{a}$ & $0.47 \mathrm{c}$ & $0.80 \mathrm{~b}$ & $40.45 \mathrm{a}$ & $42.30 \mathrm{a}$ & $38.95 \mathrm{a}$ \\
\hline & DI & $7.94 \mathrm{a}^{*}$ & $8.38 \mathrm{a}^{*}$ & $5.37 b^{*}$ & $40.45 \mathrm{a}$ & $42.30 \mathrm{a}$ & $38.95 \mathrm{a}$ \\
\hline & RI & $15.71 \mathrm{a}^{*}$ & $9.43 c^{*}$ & $11.52 b^{*}$ & $39.17 \mathrm{a}$ & $46.17 \mathrm{a}$ & $43.03 \mathrm{a}$ \\
\hline \multirow{3}{*}{ Red fruit nr plant ${ }^{-1}$} & I0 & $30.38 \mathrm{a}$ & $29.68 \mathrm{a}$ & $30.83 \mathrm{a}$ & $7.14 \mathrm{~b}$ & $8.04 \mathrm{a}$ & $8.68 \mathrm{a}$ \\
\hline & DI & $60.60 \mathrm{c}^{*}$ & $64.43 b^{*}$ & $72.75 \mathrm{a}^{*}$ & $8.01 \mathrm{~b}$ & $10.00 \mathrm{a}^{*}$ & $11.76 \mathrm{a}^{*}$ \\
\hline & RI & $57.25 \mathrm{a}^{*}$ & $46.00 \mathrm{~b}^{*}$ & $60.28 \mathrm{a}^{*}$ & $10.29 \mathrm{a}^{*}$ & $10.21 \mathrm{a}^{*}$ & $9.71 \mathrm{a}^{*}$ \\
\hline \multirow{3}{*}{$\begin{array}{l}\text { Green fruit } \mathrm{nr} \\
\text { plant }^{-1}\end{array}$} & I0 & $15.18 \mathrm{c}$ & $22.38 \mathrm{~b}$ & $25.75 \mathrm{a}$ & $2.24 \mathrm{a}$ & $1.81 \mathrm{a}$ & $2.54 \mathrm{a}$ \\
\hline & DI & $13.15 b^{*}$ & $17.23 \mathrm{a}^{*}$ & $12.25 b^{*}$ & $2.64 \mathrm{a}$ & $2.83 \mathrm{a}^{*}$ & $2.16 \mathrm{a}$ \\
\hline & RI & $6.60 a^{*}$ & $3.20 \mathrm{c}^{*}$ & $4.18 b^{*}$ & $1.94 \mathrm{a}^{*}$ & $2.41 \mathrm{a}^{*}$ & $2.83 \mathrm{a}^{*}$ \\
\hline \multirow{3}{*}{ Red fruit weight $\mathrm{g}$} & I0 & $15.44 \mathrm{a}$ & $16.36 \mathrm{a}$ & $15.47 \mathrm{a}$ & $68.47 \mathrm{a}$ & $68.98 \mathrm{a}$ & $65.43 \mathrm{a}$ \\
\hline & DI & $29.89 b^{*}$ & $31.84 b^{*}$ & $42.46 \mathrm{a}^{*}$ & $67.65 \mathrm{a}$ & $66.33 \mathrm{a}$ & $65.32 \mathrm{a}$ \\
\hline & RI & $38.24 \mathrm{a}^{*}$ & $40.33 \mathrm{a}^{*}$ & $40.17 \mathrm{a}^{*}$ & $61.69 \mathrm{a}$ & $64.34 \mathrm{a}$ & $61.58 \mathrm{a}$ \\
\hline \multirow{3}{*}{$\begin{array}{l}\text { Green fruit weight } \\
\qquad \mathrm{g}\end{array}$} & I0 & $9.97 \mathrm{a}$ & $6.65 \mathrm{~b}$ & $6.91 \mathrm{~b}$ & $33.61 \mathrm{a}$ & $42.54 \mathrm{a}$ & $35.67 \mathrm{a}$ \\
\hline & DI & $9.18 \mathrm{c}$ & $10.73 b^{*}$ & $22.31 \mathrm{a}^{*}$ & $40.43 \mathrm{a}^{*}$ & $32.89 \mathrm{a}^{*}$ & $37.00 \mathrm{a}$ \\
\hline & RI & $12.98 c^{*}$ & $14.99 \mathrm{~b}^{*}$ & $19.79 \mathrm{a}^{*}$ & $28.52 \mathrm{a}^{*}$ & $33.59 \mathrm{a}^{*}$ & $35.57 \mathrm{a}$ \\
\hline
\end{tabular}

Mean values in the rows following the same letter do not differ significantly within year at the $\mathrm{P}<0.05$. *significant differences from the $\mathrm{I} 0$ at the $\mathrm{P}<0.05$ level, $\mathrm{I} 0=$ non-irrigation, $\mathrm{DI}=$ deficit irrigation $\mathrm{RI}=$ regular irrigation 


\section{Effect of water supply and mycorthizal inoculations on bioactive compounds of yield}

In the dry year (2015) a lower nutritional quality of fruits, except the soluble solid contents ( $\left.{ }^{\circ} \mathrm{Brix}\right)$, was detected than in a wet year. Nevertheless, the mycorrhizal inoculations had a positive influence on the $\beta$ carotene and cis lycopene concentration of fruits but it was negative on vitamin $\mathrm{C}$ concentration in the wet year. In the dry year (2015), irrigation decreased the soluble solid contents ( $\left.{ }^{\circ} \mathrm{Brix}\right)$, vitamin $\mathrm{C}$, total carotenoids, lycopene and lutein concentration of tomato fruits, however in a wet year the amount of total carotenoids, $\beta$ carotene and lycopene of fruits was increased and ${ }^{\circ}$ Brix decreased under well-water supply conditions in comparison with the non-irrigated ones (Table 4).

In a dry year, under non-irrigated conditions, (M1) inoculated plants produced lower bioactive compounds, except Brix and vitamin $C$ concentration of tomato fruits than untreated plants, while the (M2) inoculated plants significantly increased the total carotenoids, $\beta$ carotene, lutein and lycopene concentration of fruits (Table 4). Using deficit irrigation, a small increase in the amount of total carotenoids, $\beta$ carotene and lycopene of fruits was detected for the (M1) inoculated plants but significantly lower $\beta$ carotene, lutein, and cis lycopene concentration of fruits, except for vitamin C, were measured for (M2) inoculated plants compared to the control (M0) (Table 4). In a wet year, under moderate water supply (non-irrigation, deficit irrigation) both (M1) and (M2) inoculated plants produced fruits containing low vitamin C, carotenoids, lutein than in the non-inoculated plants (M0) however higher cis lycopene concentration of fruits was measured for (M2) inoculated plants.

Table 4. Effect of water supply and mycorrhizal (M) treatments on quality of yield of processing tomato in dry and wet years

\begin{tabular}{|c|c|c|c|c|c|c|c|}
\hline \multirow{2}{*}{ Traits } & \multirow{2}{*}{$\begin{array}{c}\text { Irriga- } \\
\text { tion }\end{array}$} & \multicolumn{3}{|c|}{ Dry year } & \multicolumn{3}{|c|}{ Wet year } \\
\hline & & M0 & M1 & M2 & M0 & M1 & M2 \\
\hline \multirow{3}{*}{ Brix $^{\circ}$} & I0 & $8.03 \mathrm{a}$ & $7.80 \mathrm{a}$ & $8.20 \mathrm{a}$ & $3.65 \mathrm{a}$ & $4.05 \mathrm{a}$ & $4.10 \mathrm{a}$ \\
\hline & DI & $5.03 \mathrm{a}^{*}$ & $5.10 \mathrm{a}^{*}$ & $3.87 \mathrm{~b}^{*}$ & $4.45 \mathrm{a}$ & $4.00 \mathrm{a}$ & $4.13 \mathrm{a}$ \\
\hline & RI & $3.73 \mathrm{a}^{*}$ & $3.80 \mathrm{a}^{*}$ & $3.45 \mathrm{a}^{*}$ & $3.55 \mathrm{a}$ & $3.25 \mathrm{a}^{*}$ & $3.05 \mathrm{a}^{*}$ \\
\hline \multirow{3}{*}{ Vitamin $\mathrm{C} \mu \mathrm{g} \mathrm{g}^{-1}$} & I0 & $329.95 \mathrm{a}$ & $310.85 \mathrm{a}$ & $361.20 \mathrm{a}$ & $330.53 \mathrm{a}$ & $274.61 \mathrm{~b}$ & $292.65 \mathrm{~b}$ \\
\hline & DI & $286.00 \mathrm{a}^{*}$ & $293.44 \mathrm{a}$ & $304.34 \mathrm{a}^{*}$ & $418.24 \mathrm{a}^{*}$ & $336.18 \mathrm{c} *$ & $373.77 b^{*}$ \\
\hline & RI & $272.88 \mathrm{a}^{*}$ & $288.71 \mathrm{a}$ & $272.66 \mathrm{a}^{*}$ & $333.56 \mathrm{a}$ & $204.89 c^{*}$ & $236.14 b^{*}$ \\
\hline \multirow{3}{*}{$\begin{array}{c}\text { Total } \\
\text { carotenoids } \\
\mu \mathrm{gg}^{-1}\end{array}$} & I0 & $136.30 \mathrm{a}$ & $76.02 \mathrm{~b}$ & $146.50 \mathrm{a}$ & $306.32 \mathrm{a}$ & $244.44 \mathrm{~b}$ & $258.72 \mathrm{~b}$ \\
\hline & DI & $106.27 \mathrm{~b}^{*}$ & $119.49 \mathrm{a}^{*}$ & $90.75 b^{*}$ & $389.50 \mathrm{a}^{*}$ & $224.50 \mathrm{c}^{*}$ & $271.10 \mathrm{~b}$ \\
\hline & RI & $94.27 \mathrm{a}^{*}$ & $93.83 \mathrm{a}^{*}$ & $80.29 b^{*}$ & $168.03 \mathrm{c}^{*}$ & $361.52 b^{*}$ & $409.51 \mathrm{a}^{*}$ \\
\hline \multirow{3}{*}{$\beta$ carotene $\mu \mathrm{g} \mathrm{g}^{-1}$} & I0 & $2.63 \mathrm{~b}$ & $1.46 \mathrm{c}$ & $3.24 \mathrm{a}$ & $13.48 \mathrm{a}$ & $9.92 \mathrm{~b}$ & $9.68 \mathrm{~b}$ \\
\hline & DI & $2.23 \mathrm{~b}^{*}$ & $2.51 \mathrm{a}^{*}$ & $1.89 \mathrm{c}^{*}$ & $10.08 \mathrm{a}^{*}$ & $10.88 \mathrm{a}$ & $9.68 \mathrm{a}$ \\
\hline & RI & $2.41 \mathrm{~b}$ & $2.99 \mathrm{a}^{*}$ & $2.97 \mathrm{a}^{*}$ & $5.44 b^{*}$ & $16.82 \mathrm{a}^{*}$ & $17.20 \mathrm{a}^{*}$ \\
\hline \multirow{3}{*}{ Lutein $\mu \mathrm{g} \mathrm{g}^{-1}$} & I0 & $1.99 \mathrm{~b}$ & $0.97 \mathrm{c}$ & $2.45 \mathrm{a}$ & $2.71 \mathrm{a}$ & $2.02 \mathrm{c}$ & $2.42 \mathrm{~b}$ \\
\hline & DI & $1.05 \mathrm{a}^{*}$ & $1.05 \mathrm{a}$ & $0.62 b^{*}$ & $2.71 \mathrm{a}$ & $1.69 \mathrm{c}^{*}$ & $2.20 \mathrm{~b}^{*}$ \\
\hline & RI & $0.69 b^{*}$ & $0.81 \mathrm{a}$ & $0.69 b^{*}$ & $1.18 \mathrm{c}^{*}$ & $2.92 b^{*}$ & $3.48 \mathrm{a}^{*}$ \\
\hline \multirow{3}{*}{ Lycopene $\mu \mathrm{g} \mathrm{g}^{-1}$} & I0 & $100.62 \mathrm{~b}$ & $57.42 \mathrm{c}$ & $113.40 \mathrm{a}$ & $204.81 \mathrm{a}$ & $167.00 \mathrm{~b}$ & $164.97 \mathrm{~b}$ \\
\hline & DI & $71.98 b^{*}$ & $91.33 \mathrm{a}^{*}$ & $67.52 b^{*}$ & $188.00 \mathrm{a}$ & $106.44 b^{*}$ & $185.22 \mathrm{a}^{*}$ \\
\hline & RI & $66.10 \mathrm{a}^{*}$ & $67.70 \mathrm{a}^{*}$ & $49.04 b^{*}$ & $95.14 b^{*}$ & $250.73 \mathrm{a}^{*}$ & $272.97 \mathrm{a}^{*}$ \\
\hline \multirow{3}{*}{$\begin{array}{c}\text { cis lycopene } \\
\mu \mathrm{g} \mathrm{g}^{-1}\end{array}$} & $\mathrm{I} 0$ & $14.28 \mathrm{a}$ & $3.53 \mathrm{c}$ & $6.52 \mathrm{~b}$ & $27.63 \mathrm{~b}$ & $21.14 \mathrm{c}$ & $34.29 \mathrm{a}$ \\
\hline & DI & $15.33 \mathrm{a}$ & $10.57 b^{*}$ & $8.95 \mathrm{c}^{*}$ & $5.70 \mathrm{c}^{*}$ & $36.67 \mathrm{a}^{*}$ & $21.23 b^{*}$ \\
\hline & RI & $6.01 b^{*}$ & $10.16 \mathrm{a}^{*}$ & $7.04 \mathrm{~b}$ & $13.36 \mathrm{c}^{*}$ & $28.76 b^{*}$ & $32.05 \mathrm{a}$ \\
\hline
\end{tabular}

Mean values in the rows following the same letter do not differ significantly within year at the $\mathrm{P}<0.05$. ${ }^{*}$ significant differences from the $\mathrm{I} 0$ at the $\mathrm{P}<0.05$ level, Irrigation: $\mathrm{I} 0=$ non-irrigation, $\mathrm{DI}=$ deficit irrigation $\mathrm{RI}=$ regular irrigation 
Relationship between mycorrhizal treatments, physiological traits, yield and bioactive compounds

During the reproductive stages of tomato, photosynthetic efficiency presented by chlorophyll fluorescence $(\mathrm{Fv} / \mathrm{Fm})$ increased using (M2) treatment under non-irrigated conditions in the dry year (Figure 2A). Therefore, further investigations aimed to reveal the relationships between the chlorophyll fluorescence $(\mathrm{Fv} / \mathrm{Fm})$ and mycorrhizal inoculations as well as their relationship with the fruit yield of tomato grown under different intensity of drought. In the dry year (2015), no significant impact of the mycorrhizal treatments on the $\mathrm{Fv} / \mathrm{Fm}$ measured during generative stages of development was detected neither under severe water stress (I0, $r=0.3982)$ nor under moderate water deficiency (DI, $r=0.3980)$. Nevertheless, the water supply conditions have significant influenced the activity of mycorrhizal fungi which determine their relationship with the yield.

In the dry year, under water deficiency (I0, DI) the mycorrhizal inoculations resulted in a small (12\%) increase in total and marketable yield while and a 33\% increase in the green fruit yield (data not shown). Under non-irrigated conditions (I0), the mycorrhizal inoculations did not significantly affect the marketable yield but they influenced the amount of green and diseased yield $(r=0.7322$ and $r=0.6245)$. Nevertheless, using deficit irrigation (DI) the mycorrhizal inoculations significantly influenced the marketable yield $(r=0.9394)$ and an increase in green fruit yield was also detected $(r=0.6112)$ (Table 5).

Table 5. Correlation coefficient $(\mathrm{r})$ between physiological traits, mycorrhizal $(\mathrm{M})$ treatments, yield and bioactive compounds of tomato fruits in the dry year $(n=16)$

\begin{tabular}{|c|c|c|c|c|c|c|}
\hline \multirow{2}{*}{ Traits $^{\mathrm{z}}$} & \multicolumn{3}{|c|}{ I0 } & \multicolumn{3}{|c|}{ DI } \\
\hline & Fv/Fm & $\mathbf{C T}^{\circ} \mathbf{C}$ & $\mathbf{M}$ & Fv/Fm & $\mathbf{C T}^{\circ} \mathbf{C}$ & $\mathbf{M}$ \\
\hline Total yield $\mathrm{t} \mathrm{ha}^{-1}$ & 0.0545 & 0.0335 & $0.5265^{*}$ & 0.3509 & 0.0181 & $0.9449 * * *$ \\
\hline Marketable yield $\mathrm{t} \mathrm{ha}^{-1}$ & 0.1213 & 0.0289 & $0.5590 *$ & 0.3737 & 0.0171 & $0.9394 * * *$ \\
\hline Green yield $\mathrm{t} \mathrm{ha}^{-1}$ & 0.3362 & 0.0576 & $0.7322 * *$ & -0.1246 & 0.0323 & $0.6112 * *$ \\
\hline Diseases yield $\mathrm{t} \mathrm{ha}^{-1}$ & 0.3348 & 0.0699 & $0.6245 * *$ & 0.2168 & 0.0273 & $-0.6115 * *$ \\
\hline${ }^{\circ}$ Brix & 0.0766 & 0.0073 & 0.4167 & -0.2456 & 0.0177 & $-0.6819 * *$ \\
\hline Vitamin $\mathrm{C} \mu \mathrm{g} \mathrm{g}^{-1}$ & 0.2225 & 0.0261 & $0.6231 * *$ & 0.0379 & 0.0152 & 0.2276 \\
\hline Total carotenoids $\mu \mathrm{g} \mathrm{g}^{-1}$ & $0.4117^{*}$ & 0.0462 & $0.8150 * * *$ & -0.3185 & 0.0141 & -0.3860 \\
\hline$\beta$ carotene $\mu \mathrm{g} \mathrm{g}^{-1}$ & $0.4230 *$ & 0.0324 & $0.7416^{* *}$ & -0.2722 & 0.0138 & -0.3946 \\
\hline Lutein $\mu \mathrm{g} \mathrm{g}^{-1}$ & $0.4269 *$ & 0.0381 & $0.7443 * *$ & -0.2252 & 0.0240 & $-0.7466 * *$ \\
\hline Lycopene $\mu \mathrm{g} \mathrm{g}^{-1}$ & $0.4003^{*}$ & 0.0403 & $0.7837 * *$ & -0.3749 & 0.0185 & $-0.5697 *$ \\
\hline cis lycopene $\mu \mathrm{g} \mathrm{g}^{-1}$ & $0.4065^{*}$ & 0.1161 & $0.9600 * * *$ & 0.1045 & 0.0275 & $-0.8973 * * *$ \\
\hline
\end{tabular}

${ }^{* * *} \mathrm{P}<0.001,{ }^{* *} \mathrm{P}<0.01,{ }^{*} \mathrm{P}<0.05, \mathrm{Fv} / \mathrm{Fm}=$ chlorophyll fluorescence, $\mathrm{CT}^{\circ} \mathrm{C}=$ canopy temperature ${ }^{\circ} \mathrm{C}, \mathrm{I} 0=$ non-

irrigation, $\mathrm{DI}=$ deficit irrigation

The hypothesis was that arbuscular mycorrhiza symbiosis through the physiological processes of host plants would stimulate the accumulation of bioactive compounds of tomato fruits under dry growing conditions. The results showed that the canopy temperature measured during reproductive stages of development had no influence on the yield and accumulation of bioactive components of tomato fruits under water scarcity (IO, DI) in the dry year (Table 5). Under non-irrigated conditions, the chlorophyll fluorescence $(\mathrm{Fv} / \mathrm{Fm})$ measured during reproductive stages influenced the all carotenoids concentration of tomato fruits (Table 5). In the dry year, under water deficiency (I0, DI) a relationship between the mycorrhizal treatments and the total carotenoids of tomato fruits $(r=0.4303)$ was found which means a $18.5 \%$ increase in the total carotenoid concentration of fruits of mycorrhized plants. On the basis of their correlations, the (M2) treatment can increase the accumulation of total carotenoids in the fruits by $9.8 \%$ compared to the (M1) treatment depending on the degree of water deficiency.

Under severe drought (dry year + non-irrigation), a closely significant relationship between mycorrhiza inoculations and total carotenoids, $\beta$ carotene, lutein, lycopene and cis lycopene concentration of fruits was detected. On the basis of correlations shown in Table 5, under non-irrigated conditions (I0) using (M2) treatment resulted in higher amounts of the total carotenoids lycopene and lutein concentration of fruits 
(34.8\%, 31.2\% and 43.4\%, respectively) than using (M1) treatment. In a dry year, using deficit irrigation (DI), chlorophyll fluorescence $(\mathrm{Fv} / \mathrm{Fm})$ had a weak positive impact on the marketable yield but its influence was weak negative on the total carotenoid and lycopene content of tomato fruits (Table 5). Under deficit irrigated conditions, a significant negative impact of the mycorrhizal inoculations on lutein, lycopene and cis lycopene concentration was detected $(r=-0.7466, r=-0.5697$ and $r=-0.8973$, respectively). Under this condition, use of (M1) treatment positively affected the bioactive compounds of tomato fruits resulting in $59 \%$ higher lutein, $25 \%$ higher lycopene and $18 \%$ higher cislycopene than using (M2) treatment under deficit irrigated conditions (Table 5).

\section{Discussion}

The importance of arbuscular mycorrhiza fungi is in the restoration of the plant water status because the transpiration increases when the soil moisture declines (Bitterlich et al., 2018) therefore the canopy temperature could be decreased. The canopy temperature was decreased significantly by mycorrhizal treatments (M1, M2) in comparison with that of untreated (M0) plants under severe dry conditions which indicates an increasing transpiration due to the AM activity. Nevertheless, the responses of the host plants are different depending on the time and use of inoculation. The photosynthetic efficiency expressed by $\mathrm{Fv} / \mathrm{Fm}$ of plants was higher in the double inoculated plants than that of plants inoculated once at sowing (M1) compared to the non-inoculated ones under severe drought while no impact of inoculations was detected under appropriate water supply conditions. The physiological processes of plants were also influenced by the mycorrhizal colonization of plant roots which can be varied by the environmental stresses. Higher spore density of AM fungi was found in the dry season than in the rainy season therefore the physiological mechanisms related with the plant development realized in the responses of plants (Lugo and Cabello, 2002; Cuenca and Lovera, 2010). Others (Nemeskéri et al., 2019b) found that mycorrhizal inoculations increased the chlorophyll fluorescence $(\mathrm{Fv} / \mathrm{Fm})$ during flowering and fruit setting of tomato but during later stages, fruit development and ripening periods it was decreased under non-irrigated conditions and it remained unchanged using regular irrigation. These studies also indicate that under severe dry conditions the beneficial effects of AM on plant growth is predominant until fruit setting while this effect is not detected in appropriate water supply conditions. In a wet year the activity of mycorrhizal fungi may be changed in the symbiosis, presumably AM inoculation together with the indigenous AMF can intensify the development of vegetative organs rather than the reproductive ones resulting in the retardation in the formation of bioactive compounds in the fruits.

It was shown that the fruit yield of mycorrhizal plants $(\mathrm{M}+)$ were higher under different intensity drought stress than in non-inoculated (M-) plants (Subramanian et al., 2006). Nevertheless, in the field conditions, the activity of AM fungi and their relationship with the yield of plants could be influenced by the weather of the years. In the dry year the use of mycorrhizal inoculation at sowing + transplanting (M2) of tomato was more favourable than once inoculation at sowing (M1), however, their effect on yield and quality would be modified by the water supplies. Drought affects not only the plant growth but morphology (e.g. hyphal length, diameter) and physiology of AM fungi living in the soil and in symbiosis with plant roots (LeyvaMorales et al., 2019). This can be proved by the results where under severe drought (i.e. dry year, nonirrigation), (M1) and (M2) treatments did not increase marketable yield compared to the untreated plants (M0). This can be explained by the fact that under severe drought, the activity of mycorrhizal fungi in the symbiosis of tomato can be changed. Nevertheless, the activity of (M2) symbiosis seemed to be less declined under low soil moistures (I0) than that of (M1) symbiosis that influenced the metabolisms of host plants and contributed to e.g. a high accumulation of carotenoids of fruits, and a large ratio of green fruit yield. As a result of deficit irrigation, the activity of (M2) symbiosis improved significantly, presumably the mycorrhizal fungi were less damaged than under non-irrigated conditions, therefore the (M2) inoculated plants produced significantly higher marketable yield and lower diseased yield than (M1) plants in the dry year. In the wet year, 
under deficit irrigation conditions, the inoculated (M1, M2) plants could better utilize the available water and produced a higher red marketable yield than non-treated plants (M0).

The beneficial effect of symbiosis on the accumulation of bioactive compounds is dependent on the mycorrhiza fungi species, host plant species and growing conditions. Our findings revealed that twice mycorrhizal treatments (M2) were more effective on the nutritional quality of tomato fruits under severe dry (i.e. dry year, non-irrigation) than moderate dry (dry, deficit irrigation) conditions, where a little increase only in the vitamin $\mathrm{C}$ content of tomato fruits could be detected. This finding partly coincided with that of Subramanian et al. (2006) who found significantly higher content of ascorbic acid and total soluble solids (TSS) of mycorrhizal plants $(\mathrm{M}+)$ than in non-mycorrhizal plants (M-) under different intensity water stress. Giovannetti et al. (2012) found that the mycorrhizal symbiosis enhanced the nutritional value of tomato fruits which realized an increased level of lycopene in fruits of mycorrhizal plants. Our results showed that under severe drought (without irrigation) twice AM inoculation (M2) increased significantly the total carotenoids, $\beta$ carotene, lutein and lycopene concentration of tomato fruits in comparison with the untreated plants. Nevertheless, under water deficiency using deficit irrigation, (M2) treatments decreased the amount of other bioactive compounds in comparison with the untreated plants (M0) in the dry year. There is no doubt the favourable effect of (M2) mycorrhizal inoculations on lycopene and cislycopene concentration of tomato fruits exists when the crop production is performed under moderate water supplies (non-irrigation, deficit irrigation) in a wet year. The use of mycorrhizal inoculations can be beneficial in sustainable agriculture because of the improvement of soils structure (Rillig et al., 2015; 2019) the water and nutrient uptake for the host plants and their biotic resistance (Frew et al., 2020). Increasing air $\mathrm{CO}_{2}$ due to climate change may be beneficial for $\mathrm{C} 3$ and $\mathrm{C} 4$ plants because $\mathrm{AM}$ fungi can promote the plant nutritional quality under elevated $\mathrm{CO}_{2}$ and protect against insect herbivores (Frew and Price, 2019; Frew et al., 2020). It was confirmed by our finding which showed that the use of mycorrhizal inoculations improved the nutritional quality and decreased the unmarketable yield of tomato under dry growing conditions.

During reproductive periods, under non-irrigated growing conditions, chlorophyll fluorescence $(\mathrm{Fv} / \mathrm{Fm})$ positively influenced the fruit weight of tomato and the expected yield $(r=0.4505, \mathrm{r}=0.3669)$ but their relationship was not detected under deficit irrigated conditions (Nemeskéri et al., 2019a) although these results came true when the different weather conditions are disregarded. According to our results, in a dry year under non-irrigated conditions the $\mathrm{Fv} / \mathrm{Fm}$ had no influence on the marketable yield of tomato but a weak correlation between them could be detected only under water deficiency as shown in Table 5 . Under water scarcity (IO, DI) the use of mycorrhizal inoculations increased the green fruit yield of tomato better than the marketable yield in the dry year. This can be related to the fact that the green fruits contain large amounts of $\beta$ carotene and lutein and the genes mediating in the lycopene synthesis are upregulated during fruit ripening resulting in the red colour of fruits (Dharmapuria et al., 2002) however, some of these genes are probably downregulated in mycorrhiza symbiosis which resulted in lower red marketable yield.

Contrary to expectations, AM symbiosis did not increase the accumulation of all bioactive compounds in the tomato fruits. As a result of (M2) treatment a higher increase in total carotenoids and lycopene content and a small increase in vitamin $\mathrm{C}$ content of fruits could be detected in comparison with (M1) treatment under severe drought. Although, the use of (M2) mycorrhizal inoculation and deficit irrigation could reach a significant increase in the yield of tomato, the bioactive compounds of tomato fruits, except for vitamin C, decreased. It can be established that in dry years under water scarcity (I0, DI) mycorrhizal symbiosis using Symbivit product increased to a small extent the total and marketable yield and to a large extent the green fruit yield, but little influence was found on the total carotenoids of tomato fruits $(r=0.4303)$. Using double mycorrhizal inoculation at sowing + transplanting (M2) the marketable yield could $50 \%$ higher and the green fruit yield $38.75 \%$ higher than in the case of single inoculation at sowing (M1) however the accumulation of total carotenoids in the fruits could be increased by $9.8 \%$ in comparison with (M1) treatment based on their correlations. 


\section{Conclusions}

Under dry conditions, mycorrhizal inoculation used at sowing + transplanting (M2) increased the photosynthesis activity (i.e. chlorophyll fluorescence Fv/Fm) of plants, improved the fruit setting and weight of fruits. Method of mycorrhizal inoculations and the dry growing conditions influenced the productivity of plants and bioactive compounds of tomato fruits. Under moderate dry conditions (dry year, deficit irrigation), (M2) inoculations positively influenced the marketable fruit yield than (M1) inoculation, but the effect of (M1) mycorrhizal treatment is more prevalent on the bioactive compounds of tomato fruits than M2 inoculations. Under severe drought (dry year, non-irrigation) use of (M2) mycorrhizal treatments was more efficient on the accumulation of bioactive compounds of tomato including all carotenoids and lycopene than the inoculation at sowing (M1). In dry year both mycorrhizal inoculations (M1, M2) increased the amount of green fruits yield and decreased the unmarketable yield of tomato. In a wet year, the effect of mycorrhizal inoculations (M1, M2) on the productivity of plants was not remarkable but improved significantly the $\beta$ carotene and cis lycopene of tomato fruits. The findings showed that under water scarcity, use of (M2) treatment results more marketable yield and $9.8 \%$ higher total carotenoids in the fruits than (M1) treatment. These results can be used in the production of processing tomato using deficit irrigation under dry weather conditions.

\section{Authors' Contributions}

Conceptualization: LH and EN; Investigation: ZP and AN; Analysis: KZSH and BA; Writing- original draft: EN; Writing-review and editing: LH. All authors read and approved the final manuscript.

\section{Acknowledgements}

This study was supported by the Ministry of Human Capacities grant Higher Education Institutional Excellence Program in the framework of the water related research of Szent István University, and grant number EFOP-3.6.3-VEKOP-16-2017-00008 and 1783-3/2018/FEKUTSTRAT.

\section{Conflict of Interests}

The authors declare that there are no conflicts of interest related to this article.

\section{References}

Agarwal S, Rao AV (2000). Tomato lycopene and its role in human health and chronic diseases. Canadian Medical Association Journal 163(6):739-744.

Agbna GHD, Dongli S, Zhipeng L, Elshaikh NA, Guangcheng S, Timm LC (2017). Effects of deficit irrigation and biochar addition on the growth, yield, and quality of tomato. Scientia Horticulturae 222:90-101. https://doi.org/10.1016/j.scienta.2017.05.004

Augé RM (2001). Water relations, drought and vesicular-arbuscular mycorrhizal symbiosis. Mycorrhiza 11:3-42. https://doi.org/10.1007/s005720100097

Bakr J, Daood HG, Pék Z, Helyes L, Posta K (2017). Yield and quality of mycorrhized processing tomato under water scarcity. Applied Ecology and Environmental Research 15(1):401-413. https://doi.org/10.15666/aeer/1501_401413 
Bakr JA (2018). Arbuscular Mycorrhizae fungi role in tomato (L. esculentum Mill.) production under water scarcity conditions PhD Thesis. Szent István University, Gödöllö (Hungary).

Baranska M, Schütze W, Schulz H (2006). Determination of lycopene and beta-carotene content in tomato fruits and related products: Comparison of FT-Raman, ATR-IR, and NIR spectroscopy. Analitical Chemistry 78(24):8456-8461. https://doi.org/10.1021/ac061220j

Battilani A, Prieto H, Argerich C, Campillo C, Cantore V (2012). Tomato. In: Crop yield response to water. In: Steduto P, Hsiao TC, Fereres E, Raes D (Eds.) FAO irrigation and drainage paper 66; Food and Agriculture Organization of the United Nations: Rome, Italy, pp 192-198.

Bitterlich M, Sandmann M, Graefe J (2018). Arbuscular mycorrhiza alleviates restrictions to substrate water flaw and delays transpiration limitation to stronger drought in tomato. Front Plant Science 9:154. https://doi.org/10.3389/fpls.2018.00154

Bona E, Cantamessa S, Massa N, Manassero P, Marsano F, Copetta A, Berta G (2017). Arbuscular mycorrhizal fungi and plant growth-promoting pseudomonads improve yield, quality and nutritional value of tomato: a field study. Mycorrhiza 27(1):1-11. https://doi.org/10.1007/s00572-016-0727-y

Candido V, Campanelli G, D’Addabbo T, Castronuovo D, Perniola M, Camele I (2015). Growth and yield promoting effect of artificial mycorrhization on field tomato at different irrigation regimes. Scientia Horticulturae (Amsterdam) 187:35-43.

Chaudhary P, Sharma A, Singh B, Nagpal A (2018). Bioactivities of phytochemicals present in tomato. Journal of Food Science and Technology 55(8):2833-2849. https://doi.org/10.1007/s13197-018-3221-Z

Chitarra W, Pagliarani C, Maserti B, Lumini E, Siciliano I, Cascone P, Guerrieri E (2016). Insights on the impact of arbuscular mycorrhizal symbiosis on tomato tolerance to water stress. Plant Physiology 171:1009-1023. https://doi.org/10.1104/pp.16.00307

Cuenca G, Lovera M (2010). Seasonal variation and distribution at different soil depths of arbuscular mycorrhizal fungi spores in a tropical Sclerophyllous shrubland. Botany 88:54-64. https://doi.org/10.1139/B09-100

Daood HG, Biacs PA, Dakar MA, Hajdu F (1994). Ion-pair chromatography and photodiode-array detection of vitamin $\mathrm{C}$ and organic acids. Journal of Chromatographic Science 32(11):481-487.

Daood HG, Bencze G, Palotas G, Pek Z, Sidikov A, Helyes L (2014). HPLC Analysis of carotenoids from tomatoes using cross-linked C18 column and MS detection. Journal of Chromatographic Science 52(9):985-991. https://doi.org/10.1093/chromsci/bmt139

Dharmapuria S, Rosati C, Pallara P, Aquilani R, Bouvier F, Camara B, Guiliano G (2002). Metabolic engineering of xanthophyll content in tomato fruits. FEBS Letters 519:30-34. https://doi.org/10.1016/s00145793(02)02699-6

Duc NH, Csintalan ZS, Posta P (2018). Arbuscular mycorrhizal fungi mitigate negative effects of combined drought and heat stress on tomato plants. Plant Physiology and Biochemistry 132:297-307. https://doi.org/10.1016/j.plaphy.2018.09.011

Ebrahim MKH, Saleem AR (2017). Alleviating salt stress in tomato inoculated with mycorrhizae: photosynthetic performance and enzymatic antioxidants. Journal of Taibah University for Science 11(6):850-860. https://doi.org/10.1016/j.jtusci.2017.02.002

Favati F, Lovelli S, Galgano F, Miccolis V, Di Tommaso T, Candido V (2009). Processing tomato quality as affected by irrigation scheduling. Scientia Horticulturae 122:562-571. https://doi.org/10.1016/j.scienta.2009.06.026

Frede K, Ebert F, Kipp AP, Schwerdtle T, Baldermann S (2017). Lutein activates the transcription factor Nrf2 in human retinal pigment epithelial cells. Journal of Agricultural and Food Chemistry 65(29):5944-5952. https://doi.org/10.1021/acs.jafc.7b01929

Frew A, Price JN (2019). Mycorrhizal-mediated plant-herbivore interactions in a high $\mathrm{CO}_{2}$ world. Functional Ecology 33:1376-1385. https://doi.org/10.1111/1365-2435.13347

Frew A, Powell JR, Johnson SN (2020). Aboveground resource allocation in response to root herbivory as affected by the arbuscular mycorrhizal symbiosis. Plant and Soil 447:463-473. https://doi.org/10.1007/s11104-019-04399

Giovannetti M, Mosse B (1980). An evaluation of the techniques for measuring vesicular arbuscular mycorrhizal infections in roots. New Phytologist 84:489-500. https://www.jstor.org/stable/2432123

Giovannetti M, Avio L, Barale R, Ceccarelli N, Cristofani R, Iezzi A, Scarpato R (2012). Nutraceutical value and safety of tomato fruits produced by mycorrhizal plants. British Journal of Nutrition 107:242-251. https://doi.org/10.1017/S000711451100290X 
Giuliani MM, Gatta G, Cappelli G, Gagliardi A, Donatelli M, Fanchini D, Bregaglio S (2019). Identifying the most promising agronomic adaptation strategies for the tomato growing systems in Southern Italy via simulation modelling. European Journal of Agronomy 111:2019125937 https://doi.org/10.1016/j.eja.2019.125937

Hart M, Ehret DL, Krumbein A, Leung C, Murch S, Turi C, Franken P (2015). Inoculation with arbuscular mycorrhizal fungi improves the nutritional value of tomatoes. Mycorrhiza 2:359-376. https://doi.org/10.1007/s00572-0140617-0

Helyes L, Lugasi A, Pék Z (2007). Effect of natural light on surface temperature and lycopene content of vine ripened tomato fruit. Canadian Journal of Plant Science 87:927-929. https://doi.org/10.4141/CJPS07022

Helyes L, Lugasi A, Pék Z (2012). Effect of irrigation on processing tomato yield and antioxidant components. Turkish Journal of Agriculture and Forestry 36:702-709. https://doi.org/10.3906/tar-1107-9

Helyes L, Szerdahelyi R, Pék Z (2000). Appreciation of fruit set dynamics in autumn tomato forcing. Acta Agronomica Óváriensis 42(2):225-232.

Leyva-Morales R, Gavito ME, Carrillo-Saucedo SM (2019). Morphological and physiological responses of the external mycelium of Rhizophagus intraradices to water stress. Mycorrhiza 29:141-147. https://doi.org/10.1007/s00572-019-00880-8

Lira LQ, de Souza AF, Amancio ADM, Bezerra CG, Pimentel JB, Moia MN, Dimenstein R (2018). Retinol and beta carotene status in mother-infant dyads and associations between them. Annals of Nutrition Metabolism 72:5056.

Lugo MA, Cabello MN. 2002. Native arbuscular mycorrhizal fungi (AMF) from mountain grassland (Córdoba, Argentina) I. Seasonal variation of fungal spore diversity. Mycologia 94(4):579-586. https://doi.org/10.2307/3761709

Nagy Z, Daood H, Neményi A, Ambrózy Z, Pék Z, Helyes L (2017). Impact of shading net color on phytochemical contents in two chilli pepper hybrids cultivated under greenhouse conditions. Horticultural Science and Technology 35:418-430.

Nemeskéri E, Neményi A, Bőcs A, Pék Z, Helyes L (2019a). Physiological factors and their relationship with the productivity of processing tomato under different water supply. Water 11(3):586. https://doi.org/10.3390/w11030586

Nemeskéri E, Horváth K, Pék Z, Helyes L (2019b). Effect of mycorrhizal and bacterial products on the traits related to photosynthesis and fruit quality of tomato under water deficiency conditions. Acta Horticulturae 1233(1):6166 https://doi.org/10.17660/ActaHortic.2019.1233.10

O'Callaghan M (2016). Microbial inoculation of seed for improved crop performance: Issues and opportunities. Applied Microbiology and Biotechnology 100:5729-5746.

Pék Z, Szuvandzsiev P, Neményi A, Tuan LA, Bakr J, Nemeskéri E, Helyes L (2019). Comparison of a water supply model with six seasons of cherry type processing tomato. Acta Horticulturae. 1233(1):41-46. https://doi.org/10.17660/ActaHortic.2019.1233.7

Rillig MC, Aguilar-Trigueros CA, Bergmann J, Bergmann J, Verbruggen E, Veresoglou SD, Lehmann A (2015). Plant root and mycorrhizal fungal traits for understanding soil aggregation. New Phytologist 205:1385-1388. https://doi.org/10.1111/nph.13045

Rillig MC, Aguilar-Trigueros CA, Camenzind T, Camenzind T, Cavagnaro TR, Degrune F, Yang G (2019). Why farmers should manage the arbuscular mycorrhizal symbiosis. New Phytologist 222:1171-1175. https://doi.org/10.1111/nph.15602

Rivero J, Álvarez D, Flors V, Azcón-Aguilar C, Pozo MJ (2018). Root metabolic plasticity underlies functional diversity in mycorrhiza-enhanced stress tolerance in tomato. New Phytologist 220:1322-1336. https://doi.org/10.1111/nph.15295

Rocha I, Duarte I, Ma Y, Souza-Alonso P, Aleš Látr A, Vosátka M, Oliveira RS (2019). Seed coating with arbuscular mycorrhizal fungi for improved field production of chickpea. Agronomy 9(8):471. https://doi.org/10.3390/agronomy9080471

Rouphael Y, Franken P, Schneider C, Schwarz D, Giovannetti M, Agnolucci M, ... Colla G (2015). Arbuscular mycorrhizal fungi act as biostimulants in horticultural crops. Scientia Horticulturae 196:91-108. https://doi.org/10.1016/j.scienta.2015.09.002

Ruiz-Sánchez M, Aroca R, Muñoz Y, Polón R, Ruiz-Lozano JM (2010). The arbuscular mycorrhizal symbiosis enhances the photosynthetic efficiency and the antioxidative response of rice plants subjected to drought stress. Journal of Plant Physiology 167:862-869. https://doi.org/10.1016/j.jplph.2010.01.018 
Salvioli A, Novero M, Lacourt I, Bonfante P (2008). The impact of mycorrhizal symbiosis on tomato fruit quality. 16th IFOAM Organic World Congress, Modena, Italy, June 16-20, 2008 Archived at http://orgprints.org/view/projects/conference.html

Shi J, Le Maguer M (2000). Lycopene in tomatoes: chemical and physical properties affected by food processing. Critical Reviews in Food Science and Nutrition 40(1):1-42. https://doi.org/10.1080/07388550091144212

Spinoni J, Szalai S, Szentimrey T, Lakatos M, Bihari Z, Nagy A, Jürgen V (2015). Climate of the Carpathian Region in the period 1961-2010: climatologies and trends of 10 variables. International Journal of Climatology 35:13221341. https://doi.org/10.1002/joc.4059

Steiner BM, McClements DJ, Davidov-Pardo G (2018). Encapsulation systems for lutein: A review. Trends in Food Science and Technology 82:71-81.

Subramanian KS, Santhanakrishnan P, Balasubramanian P (2006). Responses of field grown tomato plants to arbuscular mycorrhizal fungal colonization under varying intensities of drought stress. Scientia Horticulturae 107:245-253. https://doi.org/10.1016/j.scienta.2005.07.006

Tan JS, Wang JJ, Flood V, Rochtchina E, Smith V, Mitchell P (2008). Dietary antioxidants and the long-term incidences of age-related macular degeneration: the Blue Mountains Eye Study. Ophthalmology 115(2):334-341. https://doi.org/10.1016/j.ophtha.2007.03.083

Xie MM, Zhang YC, Liu LP, Zou YN, Wu QS, Kuča (2019). Mycorrhiza regulates signal substance levels and pathogen defence gene expression to resist citrus canker. Notulae Botanicae Horti Agrobotanici Cluj-Napoca 47(4):11611167. https://doi.org/10.15835/nbha47411561

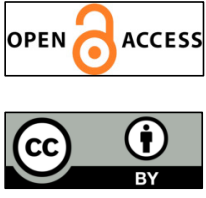

The journal offers free, immediate, and unrestricted access to peer-reviewed research and scholarly work. Users are allowed to read, download, copy, distribute, print, search, or link to the full texts of the articles, or use them for any other lawful purpose, without asking prior permission from the publisher or the author.

License - Articles published in Notulae Botanicae Horti Agrobotanici Cluj-Napoca are Open-Access, distributed under the terms and conditions of the Creative Commons Attribution (CC BY 4.0) License. (c) Articles by the authors; UASVM, Cluj-Napoca, Romania. The journal allows the author(s) to hold the copyright/to retain publishing rights without restriction. 